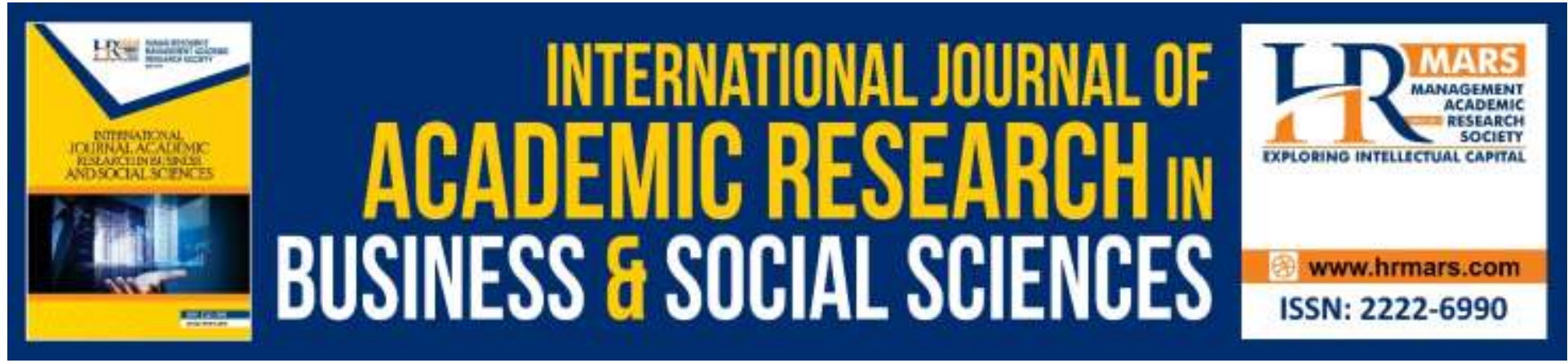

\title{
The Implementation of Malay Traditional Architectural Elements in Mukim Sabak Mosque, Kota Bharu Kelantan
}

Norhidayah Mohd Noor, Mohammad Rusdi Mohd. Nasir

To Link this Article: http://dx.doi.org/10.6007/IJARBSS/v9-i9/6285

DOI: $10.6007 /$ IJARBSS/v9-i9/6285

Received: 09 July 2019, Revised: 01 August 2019, Accepted: 23 August 2019

Published Online: 13 September 2019

In-Text Citation: (Noor \& Nasir, 2019)

To Cite this Article: Noor, N. M., \& Nasir, M. R. M. (2019). The Implementation of Malay Traditional Architectural Elements in Mukim Sabak Mosque, Kota Bharu Kelantan. International Journal of Academic Research in Business and Social Sciences, 9(9), 230-237.

Copyright: (C) 2019 The Author(s)

Published by Human Resource Management Academic Research Society (www.hrmars.com)

This article is published under the Creative Commons Attribution (CC BY 4.0) license. Anyone may reproduce, distribute, translate and create derivative works of this article (for both commercial and non-commercial purposes), subject to full attribution to the original publication and authors. The full terms of this license may be seen

at: http://creativecommons.org/licences/by/4.0/legalcode

\section{Vol. 9, No. 9, 2019, Pg. 230 - 237}

Full Terms \& Conditions of access and use can be found at http://hrmars.com/index.php/pages/detail/publication-ethics 


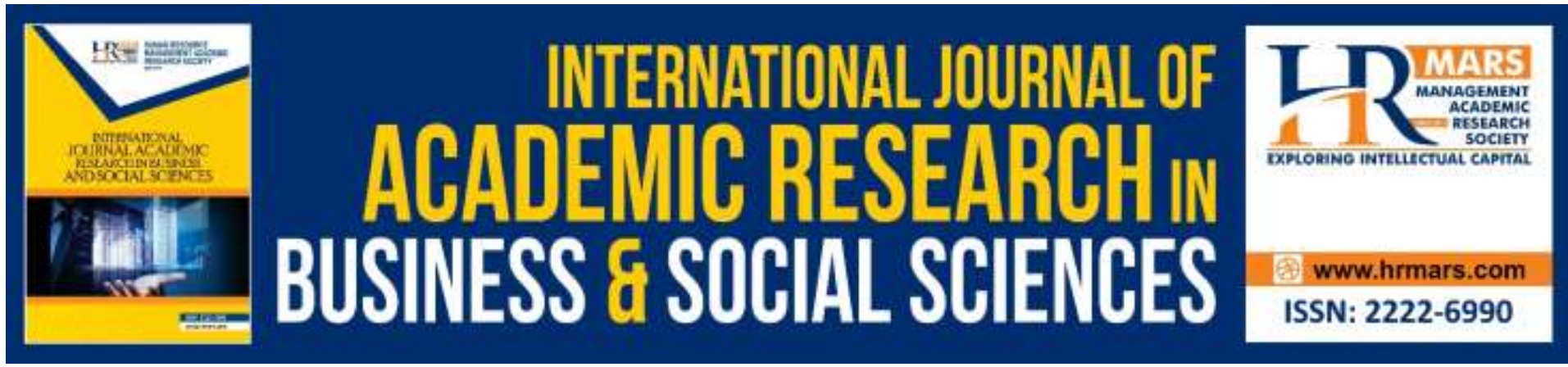

\title{
The Implementation of Malay Traditional Architectural Elements in Mukim Sabak Mosque, Kota Bharu Kelantan
}

\author{
Norhidayah Mohd Noor \\ Universiti Pendidikan Sultan Idris, Malaysia \\ Mohammad Rusdi Mohd. Nasir \\ Universiti Malaysia Kelantan, Malaysia
}

\begin{abstract}
This paper intends to investigate, examine and evaluate the implementation of traditional Malay architectural elements into Mukim Sabak Mosque at Kota Bharu Kelantan. The focus of study was to analyse the characteristics of traditional Malay Kelantan architecture based on the architectural elements appear. The elements involved consists of the roof, wall panel, pemeleh, tebar layar and gateway. Qualitative research applied during the case study conducted at Mukim Sabak Mosque. Method of collecting data gained through literature review, library research, historical research, field research and survey. Various technique have been use while recording the data such as observations, interviews, document analysis and visual recordings. Finding proved that, Mukim Sabak Mosque was successfully implemented the Kelantan traditional Malay architectural elements into it even most of the advance technology appeared. An approach from designers and developers in adapting of traditional architectural elements into a new building should be continue. This may solved the problem in getting a built-in source. Attempt to make the Mukim Sabak Mosque as a benchmark, appreciating the values of traditional architecture are important especially from the Kelantan's society itself. Parallel with that, a way of implementing the traditional architectural elements into a current development will inspire other state or regions and potentially raise it up globally.
\end{abstract}

Keywords: Architecture, Malay Architectural, Traditional Architecture, Architecture Elements.

\section{Introduction}

Undeniably, the influence of foreign culture has left deep impacts to the revolution of architecture in Malaysia. It is proven by the combination of west architectural elements in the new developmental areas such in the administration buildings, mosques, house of worships and many more (Yusof, 2014). Mukim Sabak Mosque has been choose as a place of research due to its successful accomplishment in implementing of Malay Kelantan traditional 
architectural elements on it. The elements consists of the roof, wall panel, pemeleh (boards covering the top parts of the roof), tebar layar (the triangular shape at the top of the building), and the gateway. These elements became the main attractions for the buildings in Kelantan. The same view shared by Abdullah, (2012) where he described the existence of aesthetic values inserted to the building built with traditional characteristics. Apart from that, the beauty of a building is apparent in terms of its design and ornamentations. Observation finds that these features can be see clearly in Mukim Sabak Mosque. Hence, the details of this application of traditional building elements found in Mukim Sabak Mosque will be handy to assist our societies understanding and appreciating traditional architecture values in total.

\section{Objectives}

This study conducted to identify the characteristics that symbolize the traditional Malay architectural elements of Kelantan. At the same time, researchers have the opportunity to study the style of designing traditional architectural elements tailored to the today's building technology. The ability of Mukim Sabak Mosque in interpreting its aesthetic values, which has encouraged the researcher to choose this mosque as the best and the most suitable building as a subject of the study. An in-depth study has been develop to see clearly the uniqueness of Mukim Sabak Mosque compared to most of the new buildings in Kota Bharu. It is hope this may become a source of inspiration to students, developers and communities in promoting the beauty of our local architecture elements in a new building especially in Kota Bharu.

\section{Methodology}

Overall, qualitative approaches and the designs of the case study have been use by researchers in conducting the implementations of traditional architecture elements into Mukim Sabak Mosque in Kota Bharu Kelantan. While through the methods of historical studies, field studies and comparative studies have helped researchers find the data of the traditional Malay architecture elements clearly. Meanwhile, data collection techniques involved observations, interviews, document analysis and visual recordings. This has given the opportunity to the researcher to compare the changes found in previous and current building in terms of the traditional Kelantan Malay architecture design. The conclusion towards the effectiveness of the adapting the elements discussed through the process of data analysis according to Miles and Huberman (1994).

\section{Finding}

Mukim Sabak Mosque is located in Kota Bharu. The previous location is just nearby Pantai Sabak and built in 1983. Due to wave erosion, this mosque has been relocate to a new area. Construction works have taken place in 2011 and fully accomplished in 2012. The specialties of this mosque can be clearly be seen to its design and layout. Applying traditional architecture elements to each roof design and adapting new building materials in order to highlight the new image and the designs are traditional. The mosque was built by using pillars and stages. It illustrates that the building mirrors to the characteristics of most traditional Kelantan Malay house (Kelantan, 2014). The physical image of the mosque is capable becoming the guidelines and benchmark to new developments in the Kota Bharu 2020 Local Plan. Designers and developers' ability to adapt the traditional architecture elements into Mukim Sabak Mosque proves that the image of regional architecture can be apply in various development. The ability to apply the elements of Malay traditional architecture in new 
modern development shows that both designer and developer incorporate towards pretending the local architecture.

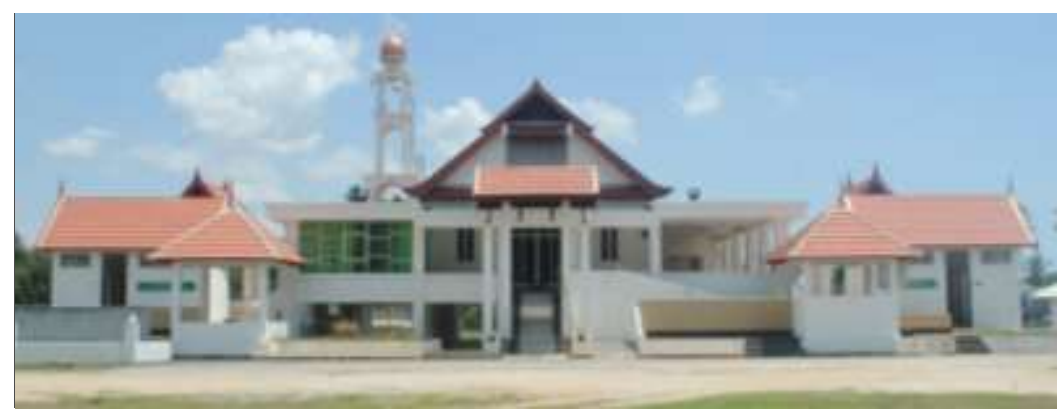

Figure 1. Front Elevation of Mukim Sabak Mosque, Kota Bharu. Source: Norhidayah, (2016).

\section{Roof}

The three main parts of a building are roof, pillars and walls. These symbolize our heads, bodies and feet according to Malay belief (Abdullah, 2012). According to Din, (1997) said that Kelantan Malay house was the only building that stood up. However, the interference of foreigners have created some varieties in designing the roof. This creates different opinions in designing the Malay Kelantan houses during at that time. The overall design of the reverse ' $V$ ' roof made the Mukim Sabak Mosque an incarnation of traditional Malay traditional architecture. The main part of the building is completed by double-layered roof and three layered roofs are used to cover the left and right wing of the building. The most outstanding features is, this mosque was built without the existence of a dome. Domes have been a priority in designing any mosques. This misconception has been proven by the completion of Mukim Sabak Mosque together with the traditional Malay elements of Kelantan into its design.
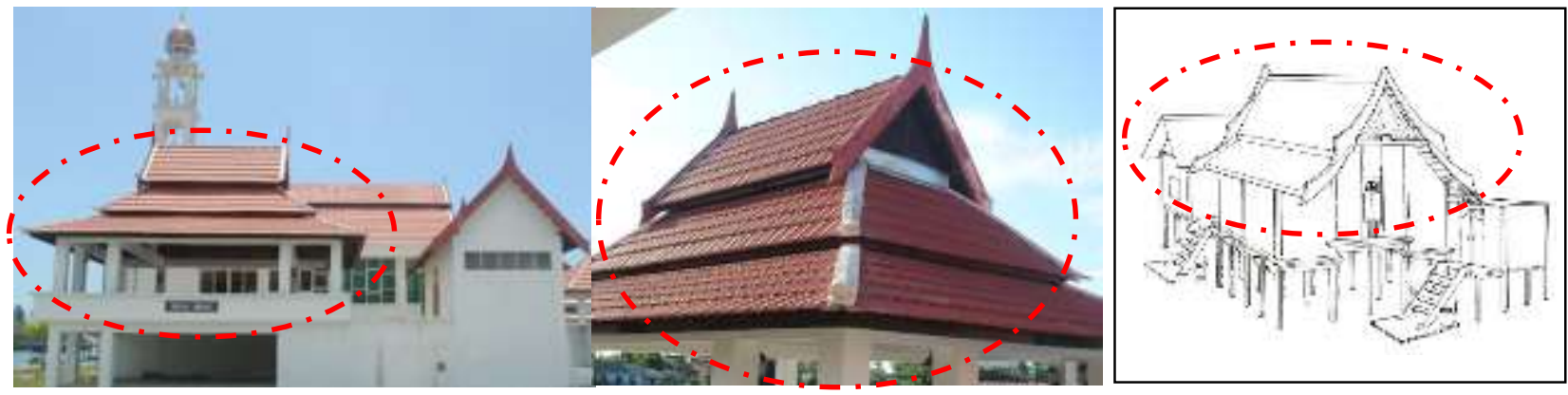

Figure 2. The Image of Roof Design for Mukim Masjid Mosque, Kota Bharu. Source: Norhidayah, (2016).

\section{Wall Panel}

Walls are the most important component of a building. A part of that, the arrangement or shape of a wall distinguishing the occupants' status. The walls found in ancient Malay houses are Dinding Janda Berhias, Dinding Janda Ria, Dinding Papan Cembung, Dinding Kajang Sebidang, Dinding Kelerai Pelupuh Buluh, Dinding Kelerai Pucuk Rebung and many more. Due to the fact, the supply was abundant during those times, so the walls founded on the natural 
resources. As an example, there were walls made from leaves, bamboo strips, woods and planks. Wood-based walls are believed to be more durable and they look even more neat and beautiful (Yusof Abdullah, 2012). For the walls found in Mukim Sabak Mosque, the arrangement of Janda Berhias implemented. In line with the current technological change, the use of concrete material paired with glass was widely use to portray the main feature of traditional architecture image.
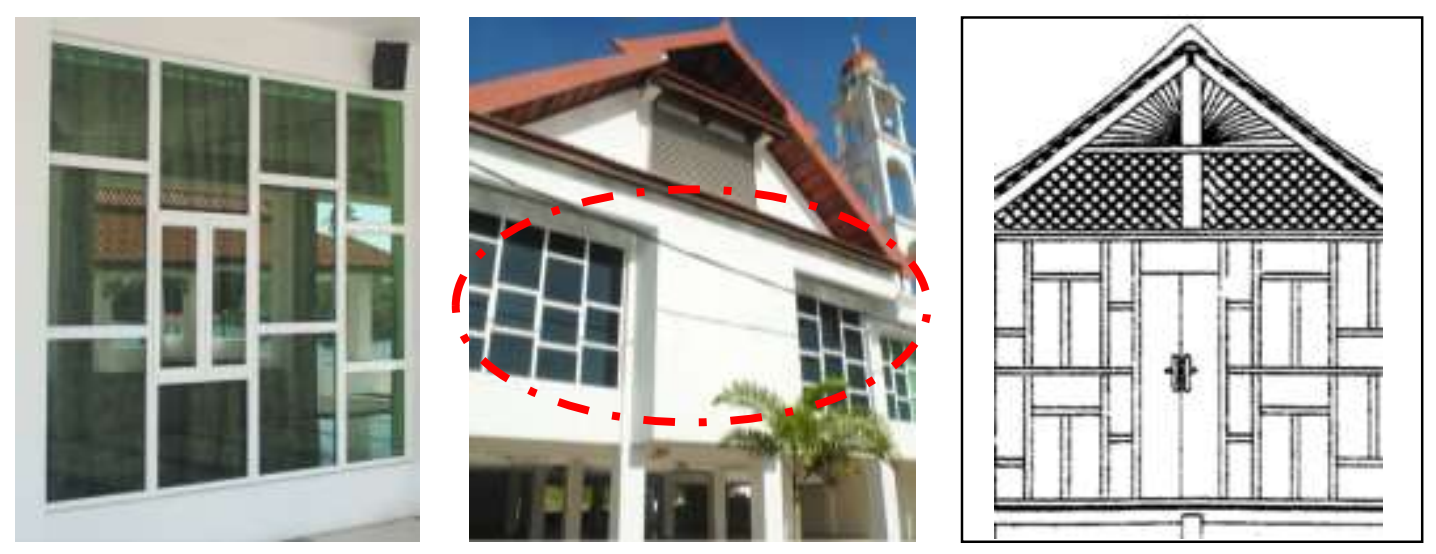

Figure 3. The Image of Wall Panel for Mukim Masjid Mosque, Kota Bharu. Source: Norhidayah, (2016).

\section{Pemeleh}

Pemeleh consists of wood panels covering the corners of roof layers. At the end of the meleh, there is a curved shape known as mata keleweng. Rashid \& Amat (2008) mentioned that pemeleh symbolizes the strength of a traditional Malay house. The shape slightly curved and sharp pointed to the top. Meanwhile, according to Shuaib (2012) pemeleh is located at the roof of the building, prominently shaped and serves as a sweetener roof. This shape of meleh illustrates the identity of its regional, especially for the state of Kelantan and Terengganu. At the end of the main roof, the two layered of meleh have been apply. Whereas on the left and right side of the building, a layer of roof has been applied.
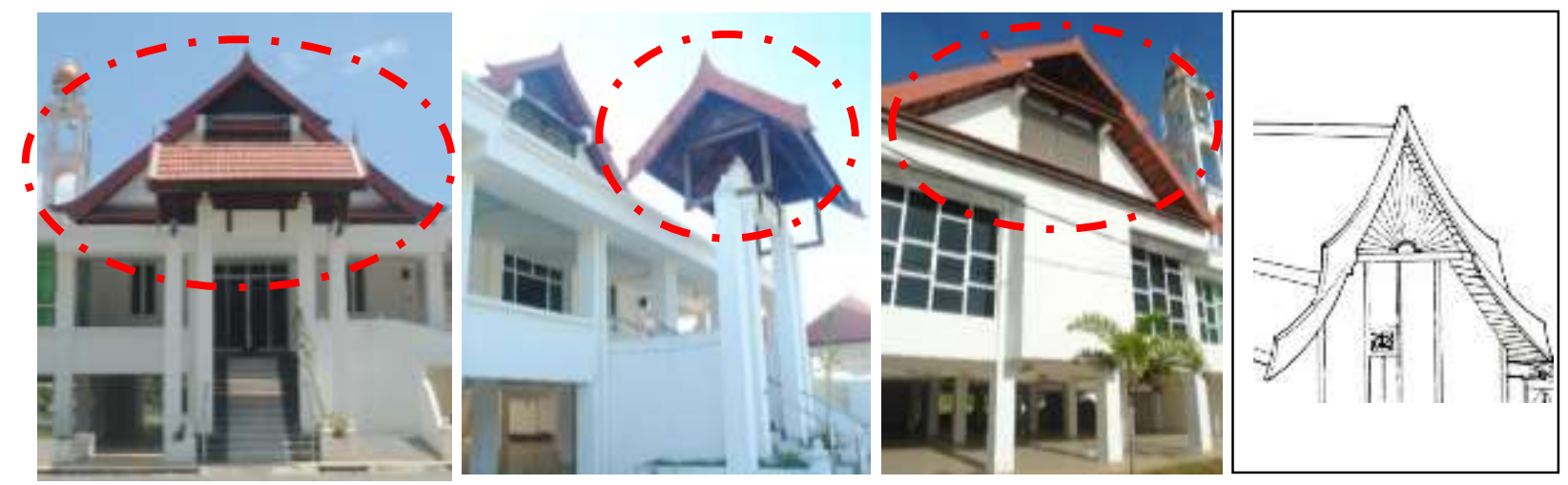

Figure 4. The Image of Pemeleh for Mukim Masjid Mosque, Kota Bharu. Source: Norhidayah, (2016). 


\section{Tebar Layar}

For the tebar layar, it refers to the space found at the bottom of the end of the roof with the inverted ' $V$ ' shape. This space covered by a piece of woods. Other views say that tebar layar is an important element in portraying the characteristics of Kelantan's traditional architectural identity and its design symbolizes the strength of local architecture towards the building (Shuaib, 2014). In addition, this space is formed through a triangular board shaped arranged with straight wood or centered curved. That arrangement will form a motive. The motives appear include of plants, animals and myth animals. Since the arrival of Islam, Malay society has acknowledged the use of tebar layar. For instance, tebar layar of kias matahari is functioning as Qiblah indicator, stated by Abdullah Mohamed (Nakula) in Persatuan Pencinta Sejarah Kelantan (2014). In order to restore the signature of Kelantan traditional architecture, Mukim Sabak Mosque has placed cosmos type of tebar layar to cover the lower parts under the roof. The design based on woods and it has layered to form a cosmos motive.
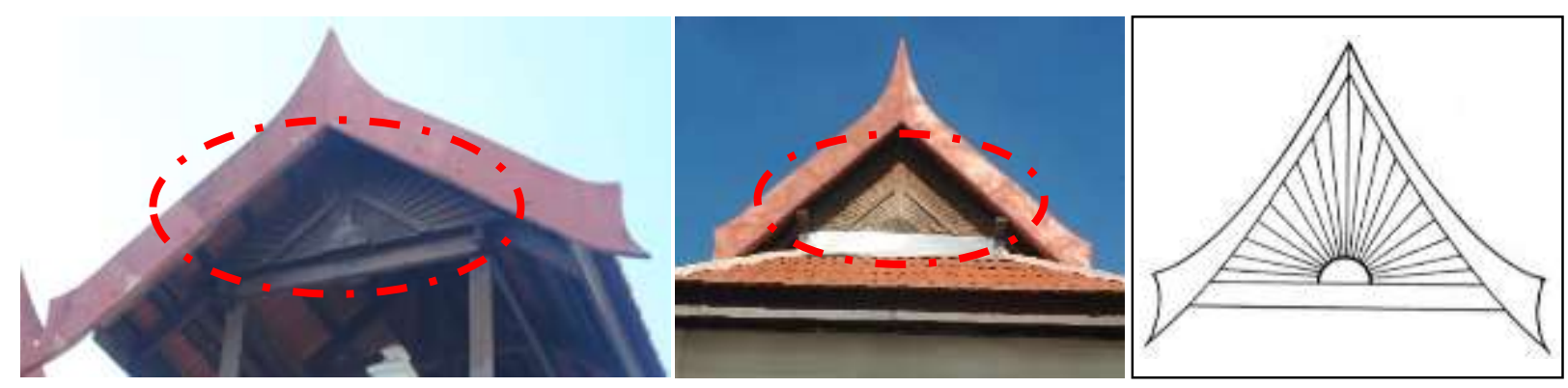

Figure 5. The Image of Tebar Layar for Mukim Masjid Mosque, Kota Bharu. Source: Norhidayah, (2016).

\section{Gateway}

Doors and gates classified as the entrance to any area of residencies. The use of doors and gates are widely used in the houses in Kelantan and Terengganu (Shuaib, 2012). He also added that this particular part of a house should be highlight to show the identity of our local architecture. Another interesting opinion also mentioned that the design of the gates is a necessity as a defense feature for a town (Saad \& Radzi, 2009). In Mukim Sabak case, the design of the entrance makes it unique and special. It is easily noticeable at when visitors enter the building. The additional elements of buah butung that come together with pemeleh and tebar layar at the upper part of the building enhance the traditional looks, which complements current modern design. 

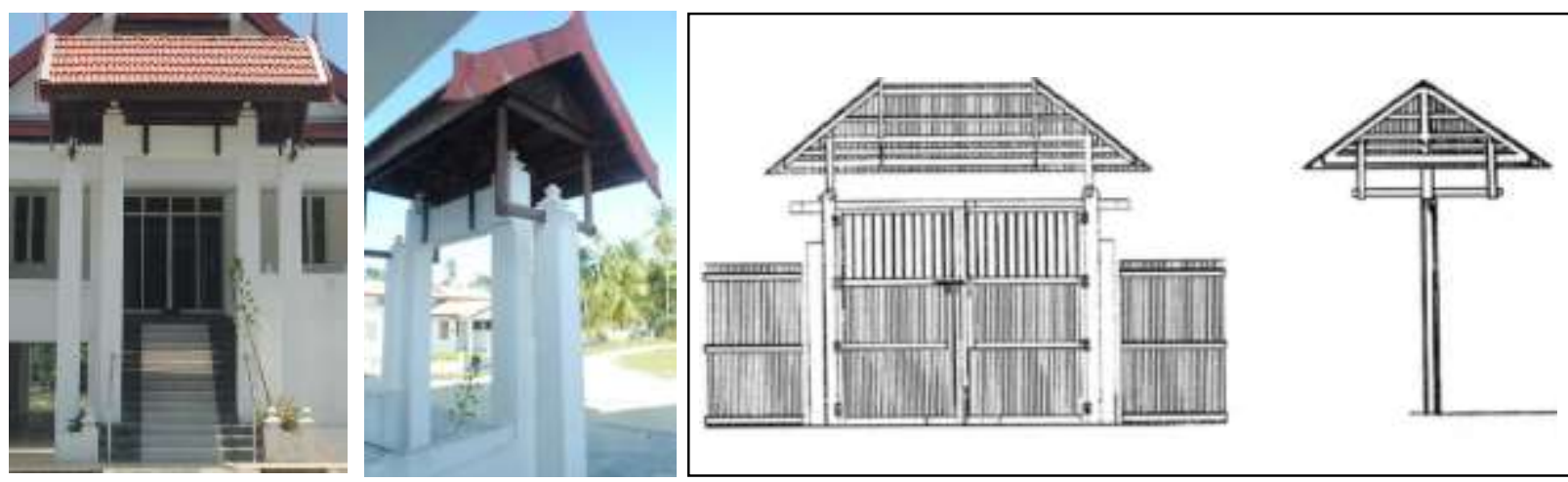

Figure 6. Image of Gateway for Mukim Sabak Mosque, Kota Bharu. Source: Norhidayah, (2016).

\section{Conclusion}

The uniqueness highlighted in Mukim Sabak Mosque is consider part of the developer's initiatives to re-introduce the elements of Malay traditional architecture not only to the locals but also to the outsiders. The variations of designs and elements in this mosque shows that traditional Malay architectural values are still being emphasize in new developments either from government and non-government parties. It is the Kota Bharu City Islamic Municipal Council intention to plan new development that may focus on the image of Kota Bharu city. This research is one of the efforts too. Through this research its hope that the elements of Malay traditional architecture will be implement into current designs. This development pattern expected and be presented globally with value that is more commercial.

\section{Acknowledgement}

We would like to express our thankful to Kaizentrenovation Centre, Tanjung Malim Perak and Tuanku Bainun Library of Sultan Idris Education University for helping us to gather all the information on behalf to complete this paper. Special thanks to our department, Department of Art and Design, Fakulti of Art, Computing and Creative Industry, Sultan Idris Education University for the full support during the research period.

\section{Corresponding Author}

Norhidayah binti Mohd Noor, Department of Art and Design, Fakulti of Art, Computing and Creative Industry, Sultan Idris Education University, Malaysia. Responsive email, ticehidayah@gmail.com. Full address, Fakulti of Art, Computing and Creative Industry, Sultan Idris Education University, 35900 Tanjong Malim Perak, Malaysia.

\section{References}

Yusof, A. M. (2014). Seni Bina Malaysia Warisan Dalam Kepelbagaian. Kuala Lumpur: Jabatan Muzium Negara.

Abdullah, Y. (2012). Warisan Seni Bina Tradisional Nusantara dan Semenanjung Malaysia. Warisan Seni Bina Melayu Terengganu (pertama). Kuala Terengganu: Yayasan Diraja Sultan Mizan.

Kelantan, M. A. I. D. A. I. M. (2014). Masjid-Masjid di Kelantan, Malaysia. (Baharin Ilias, Ed.) (pertama). Kelantan: Majlis Agama Islam dan Adat Istiadat Melayu Kelantan. 
Shuaib, A. (2012). Penggunaan unsur nilai estetika tradisional Kelantan dalam senibina kediaman kontemporari. Retrieved from http://umkeprints.umk.edu.my/1007/

Saad, S., \& Radzi, M. (2009). Urus tadbir sebuah bandaraya Islam Malaysia: Kajian kes di Kota Bharu, Kelantan. Malaysian Journal of Society and Space. Retrieved from http://www.ukm.my/geografia/images/upload/2.2009-3-suhana-melayu.pdf

Din, A. O. (1997). Rumah Tradisional Melayu Kelantan. (M. G. Addullah, Ed.). Kuala Lumpur: Kementerian Kebudayaan, Kesenian dan Pelancongan Malaysia.

Noor, N. (2016). Penerapan Elemen Senibina Tradisional Melayu Kelantan Dalam Pembangunan Baharu Rancangan Tanah Jajahan Kota Bharu 2020 (Unpublished Thesis). Universiti Pendidikan Sultan Idris, Perak.

Rashid, S., \& Amat, C. S. (2008). The Traditional Malay Architecture: Between Aesthetics and Symbolism. In Proceeding Seminar on Intellectual Property and Heritage Issues in Built Environment, Renaissance Hotel Kuala Lumpur.

Shuaib, A. (2014). Design and Heritage: Collection of Research Papers. Universiti Malaysia Kelantan.

Persatuan Pencinta Sejarah Kelantan. (2014). Senibina Rumah Melayu Kelantan. Retrieved from https://pp-sk.blogspot.com/search?q=tebar+layar 